\title{
Neformální vzdělávání rodin na př́kladu herních aktivit festivalu barokní kultury Hortus magicus
}

\author{
Petr Hudec
}

\section{ÚvoD}

Neformální vzdělávání rodin se v české společnosti děje (mimo jiné) v historickém prostředí, které má v této oblasti obrovský potenciál. $S$ akcentem na genius loci totiž zrcadlí, z čeho jsme vzešli, kdo jsme a kam směřujeme (Foltýn, 2008, s. 9).

Patřilo k dobrému zvyku vyrazit o víkendu či o prázdninách s rodinou na hrad či zámek. Za uplynulá desetiletí - či spíše již staletí ${ }^{1}$ - se kodifikovala představa tradiční prohlídky s průvodcem, která je velkou částí veřejnosti vyžadována právě $\mathrm{v}$ této podobě. $\mathrm{Na}$ druhou stranu je dnes tato forma zpřístupnění památek kritizována (viz např. Brezina, 2014), nebot́ veřejnost má zkušenosti $s$ alternativami z domova i ze zahraničí, které (mimo jiné) charakterizuje větší míra participace účastníků. Prohlídky památek se ocitly v nebývalé konkurenci na „trhu volnočasových aktivit", a pokud jejich podoba nebude reagovat na potřeby návštěvníků, ztratí o ně zájem. V důsledku toho nebude péče o památky trvale udržitelná. Britský politolog John Holden v této souvislosti upozorňuje, že $\mathrm{v}$ demokratických společnostech 21. století rozhodně nelze spoléhat na to, že by pouhá existence stávajících kulturních institucí kulturní hodnoty automaticky vytvářela. Kulturní hodnoty jsou podle něj „vytvářeny na základě vztahů, které kulturní instituce udržují s veřejností. Nebot́ veřejnosti jsou, jakožto dotované $\mathrm{z}$ veřejných prostředků, odpovědné" (Holden, 2006, s. 18). Pokud bychom akcentovali individuální a komunitní odpovědnost za kulturní dědictví, lze se vztáhnout k výroku, který Antoine de Saint-Exupéry klade do úst lišce v knize Malý princ: „Pro ten čas, který jsi své růži věnoval, je ta tvá růže tak důležitá" (1984, s. 79). Nejde tedy už jen o ochranu dědictví z minulosti, ale také o posilování odpovědnosti za dědictví, které vytváríme pro budoucnost.

Ve stále rychleji se měnícím světě jsou tedy i správci památek nuceni přehodnotit

${ }^{1}$ Prvním zpř́stupněným objektem pro veřejnost byl zřejmě clam-gallasovský zámek Frýdlant, a to od roku 1801 (Kubů, 2011, s. 37-38). 
stávající formy prezentace a interpretace památek. Citujme zde myšlenku z románu Gepard z prostředí sicilské šlechty: „Chceme-li, aby všechno zůstalo tak, jak je, musíme změnit všechno" (Tomasi di Lampedusa, 2000).

Hledání adekvátní (nové) podoby interpretace kulturního dědictví je nicméně dynamickým a dlouhodobým procesem. V zájmu zatraktivnění nabídky vtrhly do hradních a zámeckých nádvoři laciné, podbízivé aktivity s „kulturou strašidel“" vycházející vstříc požadavku „bavit se“, pořádají se nejrůznější kostýmované prohlídky atd., ${ }^{2}$ ale objevila se i serióznější nabídka. Zmiňme také nástup digitálních technologií (srov. Hudec et al., 2020).

Jak účinně naplňovat vzdělávací (i jiné) potřeby rodin při poznávání památek prakticky vyzkoušel a teoreticky popsal mezinárodně oceněný projekt Památky nás bavi (Havlůjová, Indrová, Svoboda et al., 2015), přičemž zvolenou formou se stala památková edukace (tamtéž, s. 18). Její plošné (systémové) uplatnění v ČR je však zejména z personálního hlediska delším procesem. ${ }^{3}$ $\mathrm{V}$ duchu pedagogického optimismu zde nicméně dejme prostor př́kladu dobré praxe namísto té „mrzuté“.

\section{Profil barokního festivalu Hortus Magicus}

$\mathrm{V}$ kroměřížské Květné zahradě se od roku 2014 pořádá festival barokní kultury Hortus magicus. $\mathrm{Na}$ jednu stranu navrací návštěvníky do doby zakladatele Libosadu, olomouckého biskupa Karla z Lichtensteinu-Castelcorna (1624-1695), na druhou stranu neinterpretuje tuto památku jako oživené muzeum, ${ }^{4}$ nýbrž jako cosi, co stále ještě žije vlastním životem. Rozvijí v zahradě kulturu „baroka 21. století“ (obr. 1). Z hlediska komplexnosti festivalu by se dalo hovořit o Gesamtkunstwerku: na základě studia původní ikonografie, hudebních partitur proslulého zámeckého hudebního archivu a dalších pramenů je pro návštěvníky během tř́i letních dní připraven bohatý program sestavený $\mathrm{z}$ hudebních a divadelních představení, floristické výzdoby, ohňostroje, komentovaných prohlídek zahrady, dobových her, ochutnávek jídla atd. Pro každý ročník festivalu je voleno jednotící téma vycházející zpravidla z hlavního večerního představení, které dává ideovou náplň všem dílčím aktivitám. ${ }^{5}$ Významnou návštěvnickou skupinou festivalu jsou rodiny, kterým je část programu vytvářena na míru. Kromě

\footnotetext{
${ }^{2}$ Spojení (dominantní) zábavy a vzdělávání, které je motivované ekonomickými zájmy pořadatele, je v pedagogické literatuře označováno jako edutainment.

${ }^{3}$ Srovnejme zde situaci v muzeích a galeriích, kde se profese galerijních a muzejních pedagogů etablovala a plošně rozšrírila na základě nezdolného úsilí nadšenců, které má kořeny již v osmdesátých letech 20. století (Brabcová, 2003).

${ }^{4} \mathrm{~V}$ tom můžeme poukázat na rozdíl od českokrumlovských snah, kde pořádání barokních slavností směřuje k jejich co nejvěrnější rekonstrukci (srov. Pavelec \& Slavko, 2015).

${ }^{5}$ Pořadatelem festivalu Hortus magicus je agentura Kulturní Morava (www.hortusmagicus.cz).
} 


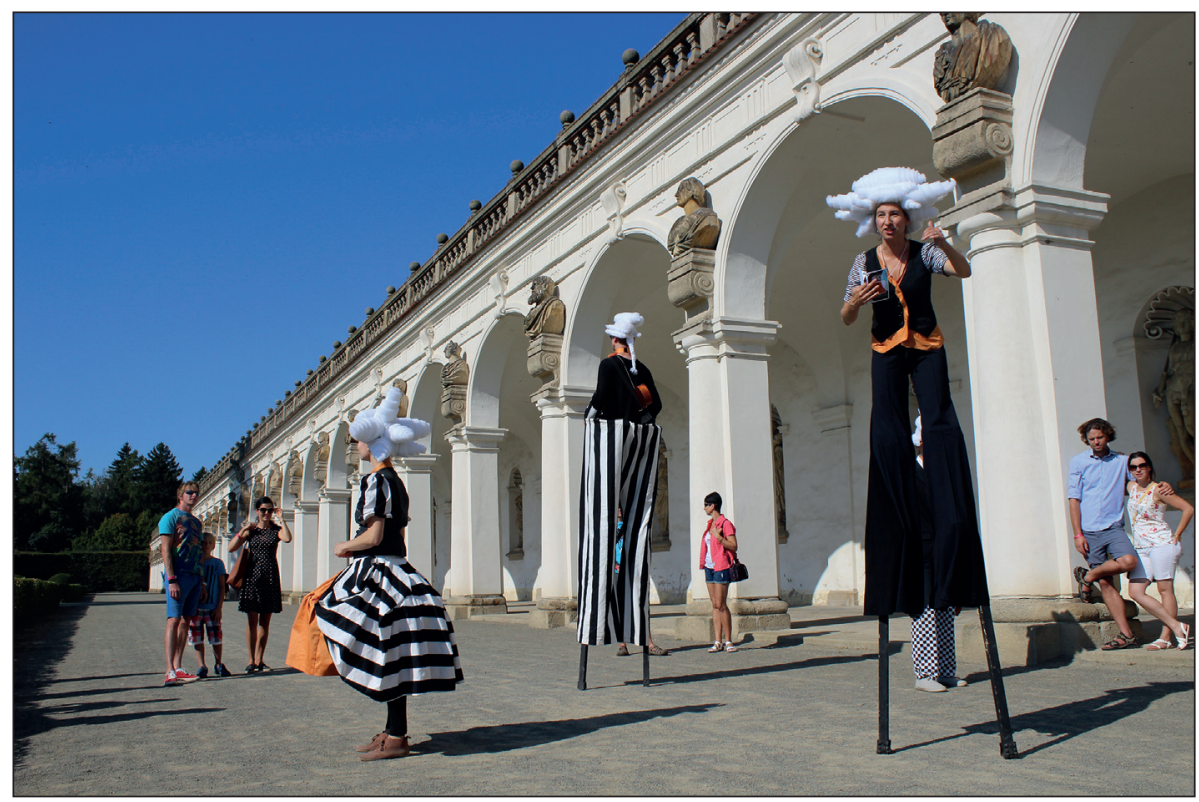

Obr. 1. Festival Hortus magicus rozvíjí v zahradě „baroko 21. stoleti““ (foto autor)

dětských představení a herního mobiliáře (např́klad barokní houpačka) je to nabídka herních aktivit dimenzovaná pro zhruba pět set osob.

\section{HRY JAKO PŘÍLEŽITOST}

\section{PRO MEZIGENERAČNÍ UČENÍ}

Hry připravované během festivalu pro rodiny jsou nabízeny formou osmi vzájemně souvisejících a provázaných stanovišt́, která jsou obsluhována lektory. ${ }^{6}$ Rodiny se po zahradě pohybují samostatně. Při vstupu do zahrady obdrží návštěvníci společně se vstupenkou herní kartu (obr. 2), která obsahuje plánek zahrady s vyznačenými stanovišti a prostorem pro otisk razítek po splnění úkolů. Aktivity jsou nabízeny během všech tří dní festivalu od 10 do 17 hodin a zájemci je mohou navštěvovat v libovolném čase a pořadí, s výjimkou jednoho stanoviště, které funguje jako cílové. Zde je účastníkům po splnění posledního úkolu předána drobná odměna.

\footnotetext{
$\overline{{ }^{6} \text { Jedná se o zaměstnance Národního památkového ústavu, lektory Muzea umění Olomouc, dobrovolníky ze }}$ souborů historického tance a šermu i brigádníky.
} 

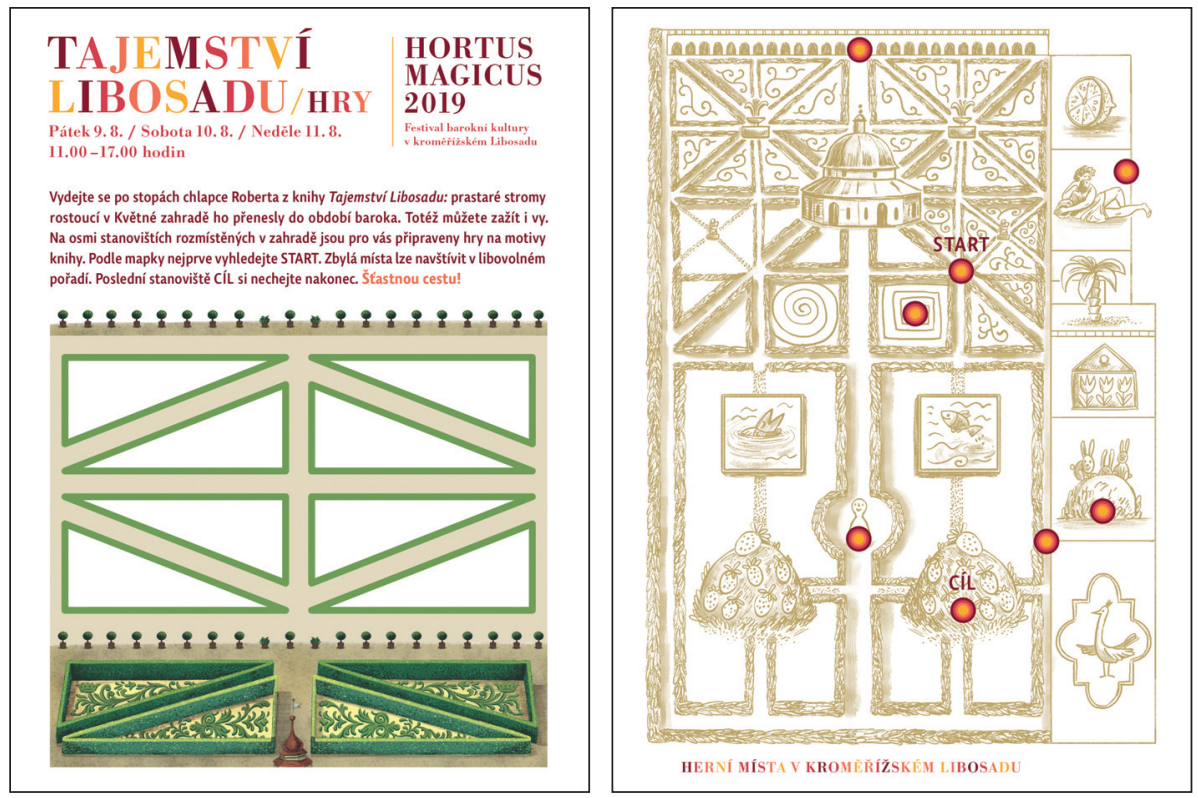

Obr. 2. Přední a zadní strana herní karty (výtvarné řešení E. Chytková, reprod. archiv NPÚ)

Z formálního hlediska mají tedy aktivity charakter akce typu "pohádkový les“. Ovšem tím, že program po obsahové stránce garantují muzejní a památkoví pedagogové, obsah stanovišst má edukativní rozměr zaměrený na intepretaci kulturního dědictví. Projevuje se to již volbou námětu her. Ty jsou zpravidla inspirovány antickou mytologií, konkrétně Ovidiovými Proměnami, které jsou určující pro ikonografii zahrady. ${ }^{7}$ Předmětem interpretace je pak dále historie zahrady, její charakter a principy, na kterých je založena, jednotlivé části památky i řemeslné postupy, pomocí nichž byla utvořena či je nadále udržována.
Nabídka je vytvářena tak, aby zážitky z návštěvy zahrady sdílela rodina společně. Tím se podporuje rodinné či mezigenerační učení: rodiče či prarodiče jsou tutory dětí, ale vznikají i situace, kdy tomu může být naopak (Havlůjová et al., 2015, s. 90). U konkrétní aktivity tak dospělí pouze nepozorují své děti, nýbrž podílejí se na procesu objevování či tvorby, chválí, povzbuzují, sdílí radost, nechávají se poučit dětmi a podobně (obr. 3).

Zastavme se ještě krátce u významu her jako svého druhu vzdělávací příležitosti pro rodiny. Jsou to právě hry a další formy výchovy zážitkem, které jsou ade-

${ }^{7}$ V roce 2016 tak např́iklad tvořily koncept prŕiběhy ze života boha Apollona. 
kvátní formou vzdělávání této návštěvnické skupiny (viz např. Pávková et al., 1999, s. 77-81; Jirásek, 2001, s. 6-16). Hry jsou obvykle považovány za přirozený způsob socializace malých dětí, za cestu, která je vede ke zkušenostnímu poznání. Obsahují informace podobně jako mýty. Díky poznávací funkci her si děti vysvětlují každodenní okolní svět a přizpůsobují se jeho řádu (viz např. Piaget \& Inhelder, 2007).

\section{Tajemství Libosadu}

Ze šesti realizovaných programů festivalových her představuje tento př́spěvek ten zatím poslední, uskutečněný $\mathrm{v}$ roce 2019. ${ }^{8}$ V témže roce vydal Národní památkový ústav knihu Tajemství Libosadu (Hudec, 2019). Jedná se o specifický formát „pohádkového či dětského průvodce po památce“, kdy je literatura prostředkem k poznávání hmotného kulturního dědictví a zároveň motivací $\mathrm{k}$ osobní zkušenosti z prožitku. Hlavním hrdinou prŕběhu je chlapec Robert, který je na prázdninách v Kroměříži u svých prarodičů. Prastaré stromy rostoucí v Květné zahradě ho přenesly do období baroka. Robert se díky tomu setkává s mnoha lidmi pečujícími o zahradu v době její-

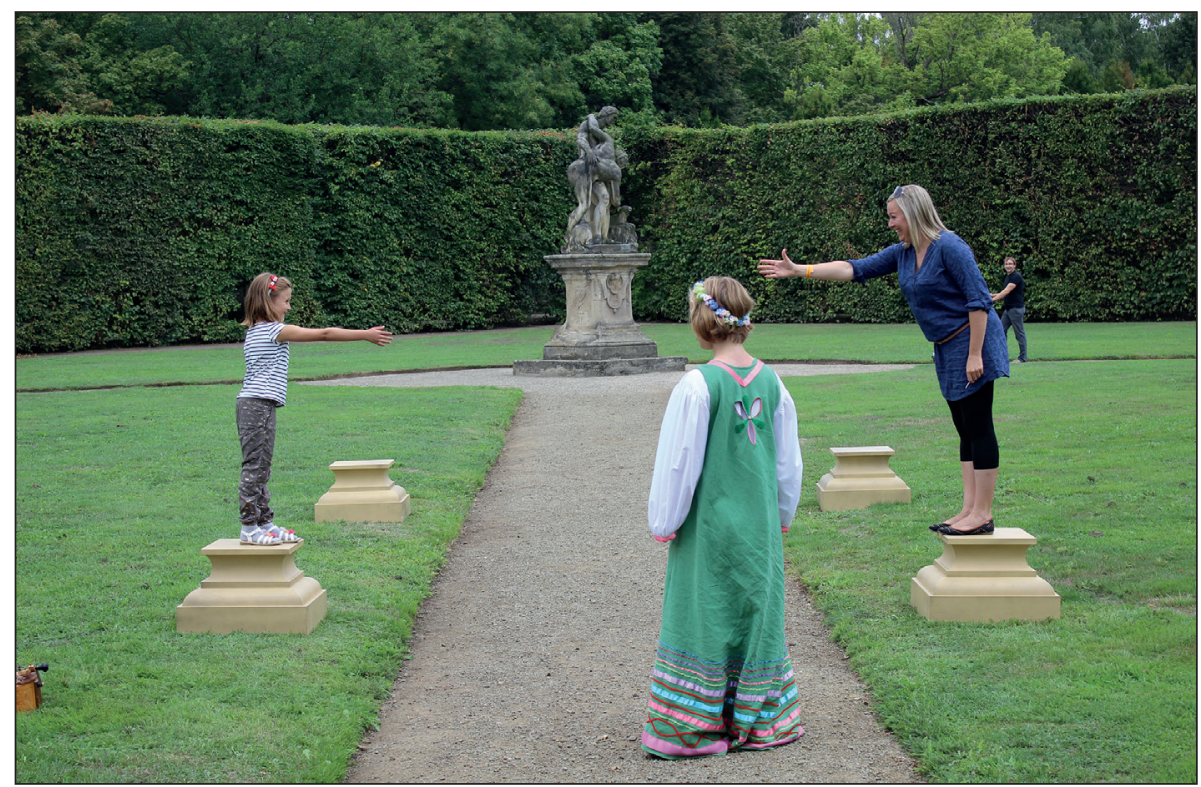

Obr. 3. Rodiče jsou plnohodnotnými účastníky mezigeneračního učení (foto autor)

\footnotetext{
${ }^{8}$ Program her připravených pro rok 2017 byl prredstaven v publikaci Památková edukace $v$ historických zahradách a parcích (Havlůjová \& Hudec, 2019, s. 226-232).
} 
ho vybudování i s vrstevníky Bohdankou a Johanem, kteří se stanou jeho průvodci při dobrodružném objevování krásy zahrady i poznávání dobových zvyklostí, profesí a reálií.

Připravená herní nabídka byla koncipována tak, že návštěvníci se vydávají po stopách Robertových dobrodružství, nebot' i festival barokní kultury Hortus magicus poskytuje př́ležitost „cestovat v čase". Herní stanoviště byla připravena na osmi místech, která odpovídají vyprávěnému př́běhu. To bylo podtrženo situováním reprodukcí působivých ilustrací z knihy na malírské stojany u jednotlivých stanovišté. Protože Robertova cesta zahradou byla započata setkáním s prastarými habry, bylo tentokrát závazné (určené) nejen poslední, nýbrž i první zastavení.

\section{Mluvící habry}

$\mathrm{V}$ návaznosti na vyprávění z knihy účastníci aktivity procházeli habrovým loubím, které bylo ozvučeno šesticí ukrytých bezdrátových reproduktorů. Pouštěné zvukové nahrávky vytvářely dojem vyprávění stromů. Dvě zvukové stopy byly rozhovorem stromů, jedna byla pojata jako vyprávění stromu pamětníka (např. „Před sto čtyřiceti lety jsem slyšel v Kroměŕíži poprvé houkání vlaku."), další vyzývaly účastníky $\mathrm{k}$ aktivitě („Ty jo, já mám pocit, že mi na kůře roste nějaká houba. Podíváš se?") nebo k vcítění se do údělu stromu („Každý rok se mi hůř a hůř dýchá.").
Následně návštěvníci vystřihovali z tvrdého papíru předtištěné obrysy habrových listů. Pomocí tuše nebo černé fixy pak doplňovali žilnatinu listů - bud' v souladu s realitou, nebo jako výtvarnou inspiraci - a následně listy kolorovali. Vytvořili si tak atribut zahrady určený $\mathrm{k}$ zavěšení na krk nebo přišpendlení na oděv.

\section{V labyrintu}

Úkolem účastníků bylo nalézt cestu do středu čtvercového bludiště z habrového živého plotu a zde ještě nalézt cestu v matematickém bludišti. To bylo vytvořeno z dvaceti pěti dlaždic opatřených čísly. Číselná hodnota na dlaždici určovala počet kroků, které hráč může udělat jedním směrem. Cílem bylo ocitnout se ve středu bludiště. Aktivita akcentující geometrický a matematický charakter zahrady se stala výzvou jak pro děti, tak pro jejich rodiče. Pro menši děti pak byla připravena alternativa - možnost házet plstěnými kroužky na trofej Minotaura (rohy na kůlu).

\section{Tajemství perspektivy}

Jedním z principů, na kterém je zahrada založena, je perspektiva. Účastníci mohli konstruovat obrázek se sloupy kolonády na principu boční perspektivy.?

\section{Vodní stroj}

Centrální zahradní stavba (Rotunda) byla budována jako vodní pavilon

${ }^{9}$ Srov. https://prima.iprima.cz/krejzovi/krejzovi-24-pomucka-pro-kresleni-perspektivy 


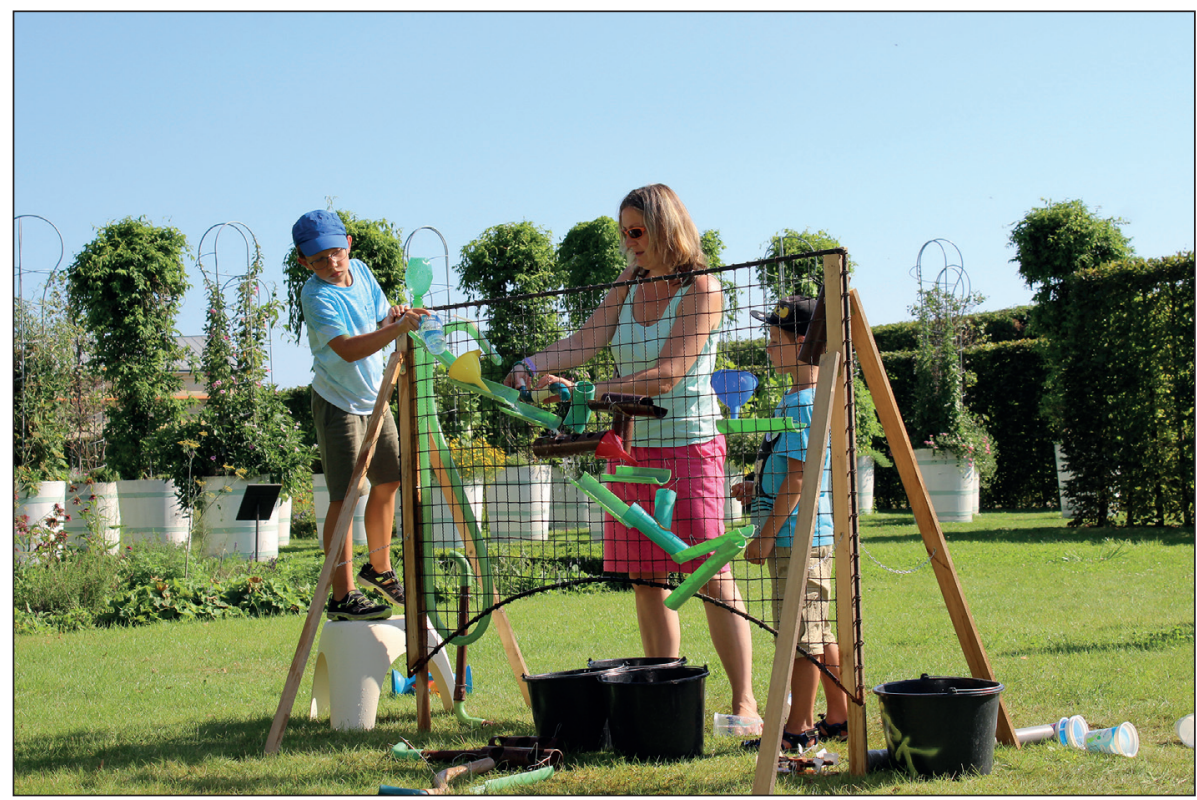

Obr. 4. Rodiny sestavovaly v zahradě vodní stroj (foto autor)

s důmyslným vodním strojem, který dokázal nečekaně smáčet návštěvníky. Protože dnes již takto nefunguje, připravili lektoři návštěvníkům př́ležitost jednak osvěžit se vodními tryskami v zahradě a jednak sestrojit vlastní vodní stroj za pomoci sady plastových lahví, hadiček, vodních mlýnků aj. (obr. 4). Aktivita opět přinesla velkou radost celé rodině a př́ležitost $\mathrm{k}$ vyučovacímu chování, mezigeneračnímu učení. Současně se při ní naplnil princip dotváření díla pomocí hry. ${ }^{10}$

\section{Čarovná grafika}

$\mathrm{V}$ návaznosti na příběh, ve kterém se Robert setkává s malířem Nypoortem, měli účastníci možnost pracovat $s$ fotokopiemi rytiny tohoto umělce, a to na místě, které je na dobovém výjevu zachyceno. Rytina byla reprodukována na průsvitnou fólii. Jejím vložením do speciálního pouzdra, které si účastníci vyrobili a kolorovali, vznikl „kouzelný obrázek“ - černobílá rytina se po vytažení z kapsle rámu změní v barevnou (obr. 5). ${ }^{11}$

\footnotetext{
${ }^{10}$ Dotváření díla není založeno na interpretační libovưli, nýbrž na pokorné snaze o odkrytí jeho smyslu a poselství - a ta se nevylučuje s kreativitou (Eco, 2015).

${ }^{11}$ Princip aktivity je představen zde: www.youtube.com/watch?v=uQRorab922I
} 

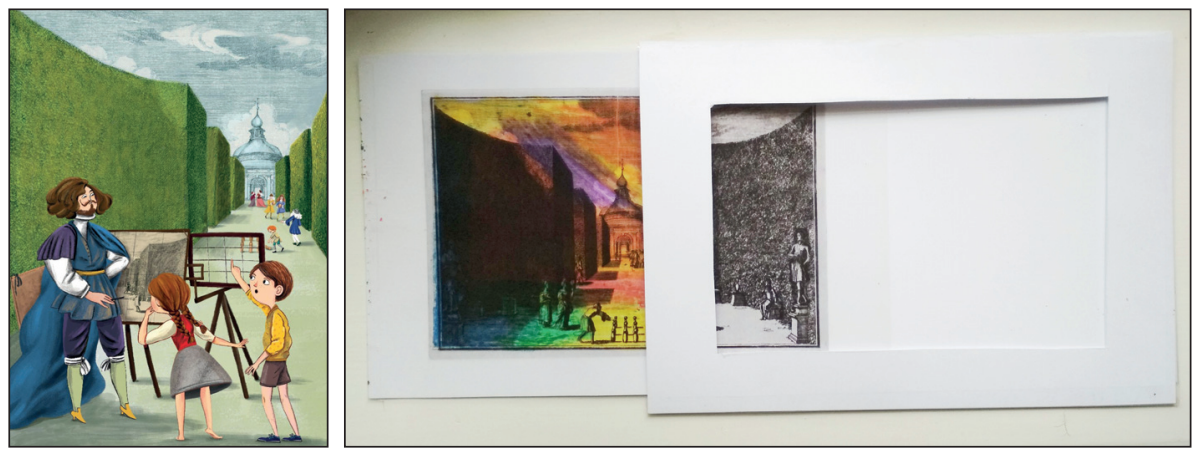

Obr. 5. Ilustrace Elišky Chytkové z knihy Tajemství Libosadu a výsledek výtvarné aktivity v zahradě v podobě posuvného obrázku (foto autor)

\section{Zahradnické práce}

Pro uvědomění si, že za krásou Květné zahrady stojí kontinuita namáhavé práce zahradníků, byly v zahradě pro účastníky (v návaznosti na vyprávění) připraveny válce pro urovnávání mlatové cesty.

\section{Luk a lyra}

Robert je $\mathrm{v}$ prríběhu nucen zvolit si jako nástroj záchrany obyvatel zahrady bud' luk, nebo lyru. Ve stejné situaci se ocitli i návštěvníci, kteří měli př́ležitost stř́let z luku do terče nebo hrát na pentatonicky laděnou lyru. Skrze nabídnuté činnosti tak zakoušeli dvě tradiční formy užívání zahrady.

\section{Setkání s biskupem Karlem}

Setkání s biskupem se odehrálo v souladu $s$ prríběhem na vyvýšeném místě jednoho z Jahodových kopečků, odkud je možné přehlédnout celou zahradu. Ne- jednalo se o sekání s kostýmovaným lektorem, nýbrž biskup byl zhmotněn podle principu „šaty dělají člověka“ materiálově věrnými replikami biskupských insignií mitry a berly. Účastníci zde dále skládali erb biskupa Karla, který ve zkratce symboliky vypovídá o roli biskupa jako správce moravské církve a současně světského knížete. Lektoři zde podle zájmu účastníků poskytli výklad k jeho jednotlivým součástem. Jako odměnu si mohli za splnění všech úkolů vybrat z nabídky odznaků (butonů) s motivy z knihy.

\section{ZÁVĚR}

Promyšlená nabídka aktivit pro rodiny na bázi vzdělávání zážitkem může být adekvátní formou užitečného trávení volného času rodin $\mathrm{v}$ historickém prostředí. Mimořádný edukační potenciál mají v tomto ohledu právě zahrady (Hudec $\&$ Křesadlová, 2015, s. 12). Tento druh neformálního vzdělávání představuje alternativu účasti rodin na klasických prohlídkách s prů- 
vodcem, kde děti jsou nezř́ídka rukojmími záliby svých rodičů a kde nedostatečné zohlednění jejich potřeb vede $\mathrm{k}$ nespokoje- nosti nejen jednotlivých členů rodiny, nýbrž také ostatních návštěvníků i průvodců (Ranochová, 2019, s. 314).

\section{LITERATURA}

Brabcová, A. (Ed.). (2003). Brána muzea otevrená. Náchod: JUKO.

Brezina, I. (2014). 11 dưvodi̊, proč zrušit oblibené pri̊vodce na hradech a zámcích. (Online). Dostupné z https://g.cz

Eco, U. (2015). Otevřené dílo. Praha: Argo.

Foltýn, D. (2008). Prameny pamèti: Sedm kapitol o kulturně historickém dédictví pro potřeby výchovné praxe. Praha: Pedagogická fakulta UK.

Havlůjová, H., \& Hudec, P. (2019). Památková edukace v historických zahradách a parcích: príklady dobré praxe. Praha: NPÚ.

Havlůjová, H., Indrová, M., Svoboda, P. et al. (2015). Památky nás bavi 4: Kulturní dédictví jako príležitost pro učení vesech generací. Praha: NPÚ.

Holden, J. (2006). Cultural value and the crisis of legitimacy: Why culture needs a democratic mandate. London: Demos.

Hudec, P. (2019). Tajemství Libosadu, Praha: NPÚ.

Hudec, P. et al. (2020). Kunstkomora v tabletu 2. Muzeum umění Olomouc.

Hudec, P., \& Křesadlová L. (Eds.). (2015). Zpưsoby edukačního využití památek zahradního umèni. Praha: NPÚ.

Jirásek, I. (2003). Vymezení pojmu zážitková pedagogika. Gymnasion, 1, 6-16.

Kubů, N. (2011). Typologie interiérové náplně na památkových objektech. Metodika tvorby interiérových instalaci a reinstalací. Praha: NPÚ.

Pavelec, P., \& Slavko, P. (Eds.). (2015). Metodika pro prípravu a realizaci historicky poučených festivit v prostredí hradũ a zámkư. Praha: NPÚ.

Pávková, P. et al. (1999). Pedagogika volného času. Teorie, praxe a perspektivy mimoškolni výchovy a zařizeni volného času. Praha: Portál.

Piaget, J., \& Inhelder, B. (2007). Psychologie ditète. Praha: Portál.

Ranochová, R. (2019). Kdo jsou a co potřebují průvodci na objektech Národního památkového ústavu. Zprávy památkové péce, 79(3), 233-384.

Saint-Exupéry, A. de (1984). Malý princ. Praha: Albatros.

Tomasi di Lampedusa, G. (2000). Gepard. Praha: Academia.

Mgr. Petr Hudec

Národni památkový ústav; e-mail: hudec.petr@npu.cz 